\title{
Pedro Lessa e a Filosofia positiva em São Paulo
}

\author{
Miguel Reale \\ Catedrático de Filosofia do Direito da \\ Universidade de São Paulo - Presiden- \\ te do Instituto Brasileiro de Filosofia.
}

I

A Jurisprudência à luz do positivismo de L. Pereira Barreto

1 - Quando se pensa na primordial significação da Faculdade de Direito de São Paulo no cenário cultural brasileiro do século passado, não deixa de ser surpreendente a reduzida repercussão do positivismo ortodoxo sob as Arcadas, em contraste com o proselitismo grangeado no seio da Escola militar, na de Engenharia ou Medicina. Indagar das razões dêsse fato talvez seja tarefa capaz de esclarecer alguns pontos obscuros no desenvolvimento de nossas idéias. A que fatôres se deve atribuir a insignificante influência do sistema de Augusto Compe na Casa do Direito, pelo menos em sua expressão integral, com tôdas as suas implicações "metafísicas" no plano religioso e político?

Ao mais ilustre dos seguidores paulistas do positivismo, ao médico Luís Pereira Barreto, logo em 1874, quando a problemática comteana mal começava a firmar raízes entre nós, não passou desapercebido o divórcio em que se 
colocavam os juristas em relação à corrente que lhe inspirava tanto entusiasmo. ${ }^{1}$

Amargas foram as palavras por êle dirigidas contra a que então como hoje se convencionou chamar "a Academia", vista como uma instituição perniciosa, "verdadeira fonte de corrupção dos nossos costumes sociais", por induzir os homens a "fazer leis, quando a ciência não as faz, mas sim as descobre".

Embora admitisse exceções, por não faltarem na Faculdade de Direito de São Paulo "intelectos eminentes que de bom grado fariam tábula rasa dessa filosofia versátil, incoerente e gárrula, que envenena o espírito da mocidade, com grande detrimento da tranquilidade social", êsses emancipados êles os reduzia a pequeno número. ${ }^{2}$

Então, como agora, prevalecia em certos círculos forte prevenção contra os "leguleios", apontados como herdeiros dos sofistas ou dos retóricos do mundo clássico, mais amantes do verossímel do que do verdadeiro, sempre seduzidos, - é a increpação que levianamente se lhes faz pelo aparato verbal e a subtileza falaciosa das formas, sem amor sincero pelo real e o concreto.

2 - Ninguém mais do que Augusto Comte expressou essa malquerença pelo saber dos juristas, cuja imagem êle forjara segundo o falso modêlo dos jusnaturalistas abstratos, que haviam tentado construir artificiosamente a sociedade e o Estado, fazendo tabula rasa do passado como inexorável fator determinante das situações sociais presentes.

Reagindo salutarmente contra as abstrações racionalistas dos filósofos franceses do século xvIII, - expres-

(1) "O Brasil já conta hoje em seu seio um pequeno grupo de positivistas, grupo recrutado especialmente na classe médica e na dos engenheiros, e que, longe de diminuir, cresce cada vez mais" L. PEReIra Barreto, As três Filosofias, 1. ${ }^{\text {a }}$ Parte - Filosofia Teológica, Rio de Janeiro, 1874, pág. LXXX.

(2) Pereira Barreto - op. cit., págs. XviII e segs. 
são última, a seu ver, da "era metafísica" que já cumprira a sua missão histórica, - o mestre do Positivismo via na Jurisprudência um fruto comprometido da Metafísica, como tal fadado a próximo desaparecimento.

Se Comte dizia, com tôdas as letras, que “dans l'état positif, qui n'admet plus des êtres cèlestes, lidée du droit disparait irrevocablement" 3 , parece-me que assiste razão a Gromele Solari quando pondera não ter sido intenção do filósofo proscrever a idéia do direito dos quadrantes da história, mas apenas anunciar o fim do primado social dos juristas ${ }^{4}$. Se na idade metafísica, os juristas tomam o lugar dos teólogos, mister é que, na idade positiva, cedam os postos de direção aos que não inventam leis, mas as descobrem, pela subordinação de suas pesquisas à unidade metódica das ciências.

A condenação, como se vê, envolvia um dado tipo de jurista, por equívoco confundido com os cultores da Jurisprudência de todos os tempos, e referia-se, mais particularmente, à concepção abstrata do Direito e da Política que norteara os revolucionários de 1789 , suscitando a reação não só de A. Comte, como de Burke na Inglaterra, ou Hegel e Savigny na Alemanha, para lembrarmos apenas os nomes mais representativos das diversas e distintas correntes de pensamento infensas ao abstratismo do "século das luzes" O que suscita a crítica veemente de Comte é a crença desmedida no poder das abstrações jurídicas, os planos de ordenação ou de reforma da sociedade mediante leis cerebrinamente concebidas, segundo ideais de pura razão, sem contacto com a realidade, sem liames com o passado, sem a necessária visão do conjunto e o imprescindível substrato de ordem moral e religiosa para soluções concretas dos problemas humanos.

(3) A. Compe - Système de politique positive, t. I, Paris, 1880, pág. 361.

(4) GIOIHLE SOLARI - Studi giuridici di Filosofia del diritto, Turim, 1949, pág. 387. 
O direito aos olhos de Compe se apresenta, assim, como "direito abstrato", ou seja, para empregarmos palavras de Solari, "é a abstrata vontade do homem que afirma as suas prerrogativas fundamentais imutáveis". Também Hegel viu o Direito como "Direito abstrato", mas compreendeu não se tratar senão do momento inicial do processo dialético da vida do espírito, ou seja, "condição de possibilidade" de objetivações ou concreções históricas progressivas, através da sociedade civil e da eticidade do Estado. ${ }^{5}$

3 - Pois bem, o que Comte afirmara sôbre o Direito, em virtude de sua poderosa reivindicação, não só da idéia do dever, mas de uma concepção unitária e orgânica da vida social, na qual o homem (a humanidade) se punha como sujeito universal concreto do processo evolutivo da história, todo o "ethos" comteano, em suma, aliás nem sempre bem compreendido, repercutia, com relativa fidelidade, na obra do paulista L. Pereira Barreto, consubstanciando-se em uma condenação singela do Direito e da Jurisprudência.

Vivendo em São Paulo, onde as idéias gerais se forjavam quase que exclusivamente sob as Arcadas, Pereira BARRETo acomodou os ensinamentos comteanos às circunstâncias do lugar e do tempo, num diálogo vivo e cheio de interêsse, que tem passado desapercebido aos estudiosos do positivismo no Brasil.

(5) Vale observar que tanto HEGer como A. Compe chegaram à concepção do "Direito abstrato" devido a dois prismas deturpados: o jusnaturalismo do sec. XVIII, como fato histórico recente, e uma errônea concepção do Direito Romano como jôgo convencional de fórmulas ou de categorias empíricas.

Sôbre o significado do "Direito abstrato" na Filosofia Jurídica de Heger, v. meu estudo "Direito Abstrato e dialética da positividade na doutrina de Hegel”, em Horizontes do Direito e da História, São Paulo, 1956, págs. 173-183. 
Para Pereira Barreto, convencido da urgência de uma "reconstrução espiritual, tendo sòmente por base a ciência demonstrada, ${ }^{6}$ a Jurisprudência é um "poder espiritual provisório", por ignorar os seus cultores que a Sociologia reclama os mesmos métodos de observação que qualquer das ciências. " Natural, pois, que visse na Academia "um pomposo cliso de jato contínuo derramando anualmente sôbre o País uma onda calculada de saber falso, de virtudes falsas, e de anarquia certa. ${ }^{8}$

O que êle prega, repetindo o mestre positivista, é a inocuidade das reformas feitas a golpes de leis, pois "o progresso jamais está na legislação, mas no seio da própria sociedade", sendo o papel do legislador "inteiramente passivo", visto como "tôda a sua ação se limita a sancionar as tendências espontâneas de uma sociedade qualquer" 9

Como era de se esperar, êsse ataque frontal à Ciência Jurídica provocou natural reação. Respostas houve irrelevantes, porque oriundas de sectários de pouca ou nenhuma consistência; outras menos apaixonadas, ditadas por motivos e razões que exigiam esclarecimentos.

Daí Pereira Barreto ter dedicado "aos legistas" tôda a $1 .^{\text {a }}$ Parte do $2 .^{\circ}$ volume de sua citada obra, publicada em 1876. São 59 páginas tôdas destinadas a elucidar a tese comteana sôbre o caráter transitório da Jurisprudência. Não há, nesse estudo, qualquer originalidade; repetem-se apenas ensinamentos de A. Comte, mas com fidelidade ao mestre: se no que se refere a outros problemas, L. P. Barreto pode ser considerado um positivista heterodoxo, nem sempre estritamente fiel a ComTe, no que tange à concepção do Direito, porém, a sua posição nada acres-

(6) Pereira Barreto, op. cit., pág. XIX.

(7) Ibidem, pág. LXIX.

(8) Ibidem, pág. xxпI.

(9) Ibidem, pág. LXIX. 
centa ao catecismo positivista. O que, todavia, nessas páginas, tem especial valia é a sua significação nas circunstâncias do meio paulista, com reflexos que logo mais nos será dado apreciar.

Admite êle, mitigando um pouco asserções anteriores, que, sendo lema do positivismo "não destruir senão aquilo que se pode substituir", a Jurisprudência dispensa qualquer justificação, representando "uma instituição de acôrdo com tôdas as leis naturais do espírito humano", por ter "a seu favor todo o pêso da história, isto é, a pressão de uma lei natural".

Não se trata, pois, de suprimí-la, mas antes de situá-la no conjunto dos fatos sociais, "para de seu conhecimento tirarmos as aplicações úteis à vida moderna". É mesmo ociosa a questão de saber se foi ou não útil e necessária nos tempos passados. Uma vez que deu satisfação a uma tendência irresistível e assim preencheu uma condição de ordem, é evidente que a sua ação não podia ser senão eminentemente civilizadora, e, portanto, necessária como condição de progresso". ${ }^{10}$

Se a Jurisprudência (ou seja, as leis jurídicas e a sua Ciência) continua sendo na atualidade de todo indispensável para a salvaguarda da ordem; se é ainda "uma válvula de segurança contra o vulcão social, um condutor benigno, que exaure mansamente o fluido explosivo das paixões populares", ${ }^{11}$ não é dito que não deva ser reputada "mero instrumento de transição, como tudo quanto é criação da metafísica em geral", 12 tornando-se, com o correr do tempo, como se deu com a Teologia, desnecessária e mesmo nociva, tanto para a ordem como para o progresso, de progressiva e salutar que fôra na sua idade própria. .

(10) Op. eit., vol. II, págs. 3.

(11) Ibidem, pág. 4.

(12) Ibidem, pág. 6. 
4 - O que preocupa ao ardoroso republicano paulista é o caráter abstrato do Direito, a que êle atribui dois vícios insanáveis: a) não ter senão soluções gerais para resolver problemas particulares; b) não ser permitido ao legista afastar-se do espírito absoluto da lei, sem cair na ilegalidade.

Se pensarmos no excessivo apêgo às soluções estritamente legais e no vício do praxismo então dominantes na doutrina e no fôro, com olvido da imprescindível unidade integrante dos fatôres histórico-sociais, não há como recusar procedência, ao menos parcial, à crítica positivista, repetida corajosamente por L. Pereira Barreto, num País, a respeito do qual, poucos meses após o aparecimento do $2^{\circ}$ vol. de "As três filosofias", o bacharel Sílvio Romero podia escrever: "O Brasil é uma País de legistas; a formalistica nos consome; tôdas as nossas questões se resolvem pela praxe (...). Um empenho, que julgamos sério e que nos absorve, é o maior fator de nossa depreciação; é a mania da legalidade, e de tudo o que com ela se parece. A melhor e mais brilhante carreira que, na idéia de todos, pode ter diante de si um moço brasileiro - é, como se diz vulgarmente, formar-se em leis; o homem, que se julga com direito a esperanças num grande futuro, põe tôda a sua mira em ir ao Parlamento exibir-se na sabença da legislação; o indivíduo do povo, em certas circunstâncias, não tendo de que viver, faz-se rábula! Assim, por tôda a parte é o sonho da lei, por tôda a parte a obstinação da praxe, como o alvo supremo.

"É porisso, continua o grande crítico, que temos uma biblioteca inteira de pequenos legistas, mas nenhum livro. de Filosofia; tantos, e, por nós, tão celebrados juristas, mas nunca tivemos um sábio. $O$ espírito que nos anima é um consórcio híbrido de teosofia e de romanticismo sôbre a velha crosta legalizante, e, se a isto juntar-se o tão bem achado séstro de palavreado e predileção pela 
retórica, compreender-se-á porque temos tantos palradores, mas nunca tivemos um crítico. "13

5 - Se o diagnóstico, no entanto, atingia quase o centro do alvo, o positivismo comteano se fundava numa errônea apreciação da história do Direito para ser capaz de oferecer-nos a terapêutica conveniente. Esta só poderia ser obra de estudiosos libertos do escolasticismo comteano, e representou e representa a mais árdua tarefa da Filosofia jurídica e da Jurisprudência no atormentado século em que vivemos, quando o desejo de concretitude é atendido, como o reclamara o gênio francês, mas com. conhecimento mais amplo e preciso da experiência social e histórica. ${ }^{14}$

A concepção da Jurisprudência como um paliativo assentava, aliás, em duas crenças, otimistas e quase ingênuas, uma quanto à "educação séria e positiva do povo", (ponto em que A. Comte não fazia senão dar colorido científico ao Iluminismo filosófico do século xviII, por êle tão àrduamente combatido) e outra quanto à possibilidade de se preverem os eventos sociais, de modo a tornar-se cada vez mais viável uma "política preventiva", com crescente diminuição da "política repressiva" 15

(13) Silvio Romero - A Filosofia no Brasil, Pôrto Alegre, 1878, págs. 148-149.

(14) Não há sociólogo ou jurista que aceite a história do Direito traçada por A. Comte, ou que possa concordar, por exemplo, com o despautério de acreditar que "tôda a Idade Média foi governada pela Igreja, sem o auxílio da Jurisprudência". o Direito, reduzido a simples "salva-vidas" ou a um precário "extintor de incêndios" nas épocas dos naufrágios ou dos cataclismos morais, foi também ilusão dos primórdios da revolução soviética, mas na Rússia já se reconhece que tôda nova ordem social implica, essencialmente, em uma nova ordem júridica.

(15) A ideologia de um Estado evanescente, ou de um Direito cada vez menos dotado de "coação", revela curiosa coincidência entre 
Há um ponto que os positivistas põem em relêvo e que merece especial meditação: é no que tange à posição dos juristas na vida contemporânea. Só a estulta vaidade poderia contestar que, de fato, os "homens da lei", máxime no decorrer da última centúria, vieram perdendo, paulatinamente, a sua posição relevante na "condução do progresso social".

Vale a pena, nesta altura, transcrever aqui as últimas palavras de L. Pereira Barreto aos legistas:

"Há apenas poucos séculos, era a classe dos legistas que formava as opiniões e concentrava em si a alta direção dos espíritos. A partir do século xvII, uma imensa modificação operou-se e o centro de direção cada vez mais deslocou-se passando para outra esfera. Outrora, era a classe dos legistas que mantinha com firmeza a vanguarda da civilização; hoje, é nesta classe que se encontram os mais veementes defensores do ultramontanismo. Na atualidade, os legistas conservam ainda as rédeas do govêrno material da sociedade; mas o govêrno moral já de todo escapou-lhes das mãos. Hoje, é só das regiões superiores da ciência que descem as correntes de opiniões, que põem em movimento todo o vasto maquinismo social. A classe

marxistas e positivistas, ambos fazendo apêlo a um estágio intermédio de ditadura: do proletariado uma, do sacerdócio positivista a outra. Um neopositivista, como PONTES DE MIRANDA, falará, fundandose em metáforas científicas, em "diminuição do quantum despótico" (Cfr. Introdução à política científica, Rio, 1924, caps. I e II).

PEREIRA BARRETo era extremado quanto à possibilidade de previsão nas ciências sociais, chegando a escrever com admirável candura: “É tal a invariabilidade das leis naturais e tão completa a dependência dos nossos atos morais para com elas, que, dado um povo e o seu grau de civilização, podemos predizer com segurança qual será o seu número de crimes para um ano qualquer" (Op. cit., vol. II, pág. 55).

Sôbre êste ponto capital, PEDRo LESSA, como veremos logo mais, tomou posição nítida e realista, a propósito da teoria histórica de BUCKLE, 
dos legistas parece atualmente fatigada de caminhar; dir-se-ia que a ciência a assusta; é um sintoma grave! Na marcha da evolução, parar é suicidar-se". ${ }^{16}$

Indo, porém, ao âmago do problema, talvez não seja tão desesperadora a posição dos juristas deveras compenetrados de sua tarefa no complexo dos problemas humanos. Ninguém poderá esperar salvação oriunda só do Direito, mas, sem o Direito, também não haverá salvação digna do homem. Nem se pode falar sèriamente em qualquer transformação social que não se consubstancie em uma "idéia de Direito".

A questão fica mal posta em têrmos de hegemonia ou de primado nos quadros e categorias da inteligência diretora, sobretudo quando se desfralda o pendão do técnicismo ou da técnocracia, que, no fundo, representaria a subordinação dos homens às coisas, o govêrno insensível das máquinas e das estatísticas sôbre as mais nobres exigências da liberdade instituidora do espírito.

Não creio que os juristas tenham a pretensão de representar a classe diretora por excelência, mas é certo que, nos momentos cruciais da história, souberam ser elementos de equilíbrio ou de harmonia no envolver dos conflitos humanos, desempenhando verdadeiro papel de guias, como se deu em Roma com os jurisconsultos e na Idade Média com os glozadores.

Quando agora tanto se investe contra os bacharéis, e será campanha salutar contra certos males do bacharelismo, - é o caso de perguntar se o desprêso pelo Direito, de um lado, e, de outro, a perda da dignidade da Jurisprudência por parte dos juristas mesmos, não terá sido uma das causas da crise que nos atormenta.

(16) Op. cit., vol. 2., pág. 59. 
II

Defesa da Jurisprudência pelos próprios positivistas

- Posição de Alberto Sales, Alfredo Egydio e João Monteiro.

6 - Compreende-se como devem ter repercutido sob as Arcadas as objurgatórias de L. Pereira Barreto e dos positivistas, suscitando aplausos e revides.

É possível que a geração acadêmica de 1875 a 1890 , pelo que nela havia de exponencial, tenha vivido com intensidade a problemática comteana, quer através da obra de Pereira Barreto, quer, como é mais provável, pela leitura direta de autores europeus, a todo instante invocados nos jornais estudantis da época. ${ }^{17}$

No dizer do Ministro Edmundo Lins, o livro de Pereira Barreto, com as demais obras da nascente doutrina, teria influído profundamente sôbre dezenas de estudantes da Faculdade de Direito, aos quais estava reservado papel do mais alto relêvo na vida nacional, como, por exemplo, Júlio de Castilho, Borges de Medeiros, Silva Jardim, Lúcio de Mendonça, Alberto Sales, João Pinheiro, Rodrigo OT́távio, Almeida Nogueira, Rivadavia Correia, Alcydes Maia, Basílio Magalhães, Vicente de Carvalho, Pedro Lessa. ${ }^{18}$

(17) 亡́ bem característico de nossa evolução mental, como já pôsto em realce por Sílvio Romero, o vêso brasileiro de não se dar valor ao que entre nós se escreve, preferindo-se, às vêzes, receber, por reflexo de autores alienígenas o que já é moeda corrente entre pensadores nacionais.

Essa carência de sentido de continuidade, no desenvolvimento intrínseco das experiências mentais, traduz certo grau de imaturidade, de falta de confiança nos valores próprios.

(18) v. Ivan Lins - $O$ positivismo no Brasil, separata de "Decimalia", pág. 9.

A êsses nomes podemos acrescentar outros, como os de DEMÉtrio Ribeiro, José Leão e AMÉrico de CAMpos. 
Basta, no entanto, a leitura dêsses nomes para se reconhecer que bem poucos permaneceram apegados a $\mathbf{A}$. Cомте, se é que se subjugaram algum dia a seu sortilégio. Em geral, o filósofo francês não chegou a monopolizar os espíritos, atraídos por outras doutrinas, como as de StuarT Mill, Spencer, Haecikel, Taine, Littré, ou Ardigò, que engrossaram a corrente do "naturalismo", ou "Filosofia positiva", ou "Filosofia cientifica", ou que melhor nome se possa dar àquele movimento de idéias que, até o advento da primeira Guerra Mundial, elaborou uma cosmovisão tranquila e otimista, fundada nos triunfos das ciências naturais, e cujas idéias mestras, graças às quais se pretendia ter dado início a um novo ciclo de cultura, revelaram bem pouca densidade especulativa.

Já foi dito com razão que o positivismo, tomado êste têrmo em sentido lato, com a sua crença no determinismo universal; na evolução como lei geral do cosmos; no progresso indefinido; no primado iluminista do saber científico na unidade metódica modelada segundo os cânones indutivistas então dominantes na Física e na Biologia; na

Como pondera JoÃo CAMILlo de Oliveira Torres, "graças às condições sociais peculiares a uma escola de direito, dominou ali o Positivismo dissidente, que se apresentou caracterizado por um acentuado criticismo no plano lógico e um republicanismo de aspecto nìtidamente revolucionário no plano das realidades político-sociais" ( $O$ Positivismo no Brasil, 2.a ed., 1957, págs. 152 e segs.)

Sem chegar ao extremo de afirmar, com êste escritor mineiro, que "o Positivismo, no sentido lato, foi a causa (sic) da República" (op. cit., pág. 74) é inegável que a Filosofia positiva, de A. Comte a $H$. SPENCER, se influiu também na formação de alguns monarquistas ilustres, sempre coincidiu com os ideais republicanos nas últimas décadas do Império. Assiste, aliás, razão a J. CRUZ Costa quando estende ao Brasil o juízo de Alvaro Ribeiro sôbre a entrada do Positivismo na cultura portuguêsa, não "pelos seus méritos de doutrina científica e filosófica, mas porque serviu um movimento histórico-político", realizando-se, como na obra de Teófilo Braga, "a simbiose da doutrinação positivista com a doutrinação republicana" ( v. O positivismo na Repriblica, São Paulo, 1956, pág. 14). 
capacidade emancipadora do homem sôbre a natureza; na certeza da crescente e cada vez mais rigorosa quantificação do qualitativo o do valioso, constituíu o estado de espírito de tôda uma geração, fundado num cabedal de convicçóes que assegurava aos homens certa tranquilidade, tanto para viver como para morrer. Se, na realidade, compararmos as obras do naturalismo positivista ou científico do último quartel do século passado, perceberemos notáveis diferenças de perspectivas, inclusive determinadas pelos coeficientes pessoais de originalidade dos distintos autores, mas o que nelas sobreleva é um substrato único de pressupostos, um denominador comum denunciando o parentesco próximo de teorias que se degladiavam na superficie inquieta ou revolta das ondas, mas sôbre as camadas serenas de uma mesma concepção do homem e do cosmos.

Livros por exemplo, como o de Sílvio Romero, Doutrina contra doutrina, ${ }^{19}$ contrapondo com veemência $\mathbf{A}$. Comte a Herbert Spencer, chegam-nos hoje com vigor atenuado, como uma disputa entre irmãos ou primos, quando o tempo decorrido nos ensina não terem resistido à revisão crítica, nem às exigências renovadas da ciência, ou às ansiedades do mundo contemporâneo, os alicerces $\mathrm{e}$ as estruturas que sustinham a ambos os contendores.

Até certo ponto desprevenidos quanto às trincas $\mathrm{e}$ fendas que surdamente iam solapando o esplêndido edifício das convicções burguêsas triunfantes, os homens do último quartel do século passado tiveram a ventura de ser partícipes de um mesmo estado de alma, vivendo com autenticidade o - "espírito da época".

Daí não se poder atribuir a êste ou àquele pensador, do Norte ou do Sul, o mérito de ter introduzido no Brasil

(19) Silvio Romero, Doutrina contra doutrina, Rio de Janeiro, 1894. 
as idéias do tempo, que aqui chegaram através dos mais diversos veículos de divulgação.

7 - É nesse panorama que devemos, pois, situar, com mais acêrto, a geração de Pedro Lessa, indagando da mentalidade reinante na Faculdade de Direito de São Paulo. Para tanto, refiro-me a duas figuras, hoje quase esquecidas, mas que desempenharam papel relevante entre os seus contemporâneos, e a um processualista, cujo nome se impõe até hoje nas letras jurídicas pátrias.

Refiro-me a Alberto Sales, ao senador Paulo Egydio de Oliveira Carvalho e ao professor João Pereira Monteiro, que representam, respectivamente, diretrizes filosófica, sociológica e jurídico-positiva. ${ }^{20}$

O primeiro, irmão do presidente Campos Salles, pertenceu a um grupo de estudiosos de Campinas, que devera merecer maior atenção dos cultores da história de nossas idéias, não só pelo que representaram de positivo na formação da ideologia republicana, como também pelos riscos em que puzeram a unidade nacional, quer, por falso regionalismo, quer por demasiado apêgo a pretensas leis desintegradoras dos organismos sociais, destinados a inexoráveis desmembramentos. ${ }^{20 \mathrm{a}}$

(20) O critério que presidiu à escolha dêsses três nomes prende-se à atenção por êles dispensada à problemática jurídica, sem implicar no esquecimento de outros valores exponenciais do positivismo em São Paulo, está ainda por se fazer a história do que representou a "filosofia positiva" no cenário cultural paulista, mesmo com relação ao movimento republicano. Nada justifica o silêncio que cerca certos nomes de nosso positivismo heterodoxo, como é o caso, por exemplo, do médico e lider republicano de Guaratinguetá, Lycurgo SANTos, o mais conseqüente de nossos seguidores de LITTRÉ, e dotado de notável erudição. Cs. dêste autor os seguintes trabalhos: Duas palavras sôbre a Filosofia Positiva e o Espiritualismo, Campinas, 1888; LITTRÉ, (Comemoração do $4 .^{\circ}$ aniversário da morte do chefe da Filosofia positiva), São Paulo 1885.

(20a) O separatismo, tanto em São Paulo como em outros Estados, foi idéia acolhida por liberais e republicanos, chegando a suscitar vivos debates (Cfr. George C. A. BoEHRER - Da Monarquia à Repu- 
A Alberto Sales devemos várias obras que ainda se lêem com grande interêsse, especialmente as que escreveu como um dos fautores da República. O seu volumoso trabalho Política Republicana, editado no Rio em 1883, assegura-lhe posição eminente entre os teóricos da propaganda republicana, ao lado de Assis Brasil. Mas, enquanto o lider gaucho desenvolve o seu belo ensaio $A$ república federal (3." ed., São Paulo, 1887) segundo critérios estritamente jurídico-políticos, o paulista sente atração pelas idéias gerais, buscando o fundamento filosófico dos problemas da sociedade e do Estado: "A harmonia entre o Estado e a evolução social, tão necessária presentemente, pondera êle, só poderá operar-se por uma justa aplicação das doutrinas positivas ao govêrno das sociedades", pois "o sistema filosófico positivo é o único que atualmente nos pode salvar da extraordinária anarquia mental. " 21

blica (História do Partido Republicano do Brasil, 1870-1889), trad. de Berenice Xavier, Rio, págs. 111 e segs.

ALBERTo SALES foi o teórico do separatismo paulista, procurando dar-lhe fundamento filosófico e científico. Assim é que, em um pequeno livro intitulado $A$ Pátria paulista, Campinas, 1887, legitima o movimento à luz do evolucionismo de SPENCER e das conquistas da Biologia e da Sociologia, filiando-o "naturalmente, como processo político especial, à lei geral do progresso em Sociologia" (pág. 91).

(21) Política Republicana, cit., pág. 15. Aliás, o próprio Autor observa, no introito dêste livro, que, para a organização de seu trabalho, não se inspirou apenas em publicistas como TOCQUEVILLE, BLUNtschli, laboulayaye, tavares Bastos ou Pimenta Bueno, mas também nos ensinamentos de A. Comte, LitTré, Spencer e Stuart Mill. Sôbre a teoria política de ALBERTo SALES, v., ainda, os seguintes estudos: $O$ ensino público, São Paulo, 1901; Catecismo republicano, São Paulo, 1885; e a Introdução que escreveu para um livro planejado sôbre $O$ Govêrno popular (publicação póstuma da "Rèvísta do Brasil", vol. 72, Dez. de 1921, págs. 330 e segs.) Sua obra, como se reconhece em nota da citada Revista de MonTETRo LOBATo, "marcou época na evolução das idéias no Brasil", muito embora nem sequer seja lembrado em livros que tanta importância dão ao anedotário da "Igreja Positivista". 
Para os objetivos de nosso trabalho, o que mais nos deve interessar é o seu Ensaio sôbre a moderna concepção do Direito, publicado em São Paulo, em 1885. Não que êsse estudo revele originalidade maior no fundo ou na forma, mas vale como índice da mentalidade reinante, propensa a aceitar as lições de LITTRÉ ou de SPENCER como verdades definitivas, sem conhecimento direto das contribuições de Descartes, Espinosa, Grocio, Rousseau ou Kant, a respeito das quais, no entanto, emite juízos temerários, revelando conhecê-los apenas através de informações precárias ou mal assimiladas. ${ }^{22}$

Isto posto, poder-se-ia julgar a citada obra de Alberto SALEs destituída de qualquer significado, mas há alguns pontos que nela merecem nossa atenção, no que tange aos problemas jurídicos, tratados com menos insegurança.

Ao expor "as tentativas de uma concepção positiva do Direito", começa por lembrar o papel desempenhado pela Escola Histórica, referindo-se a Burke, Hugo e Savigny.

Pena é que o expositor, também nêsse passo, incida no vício capital de olhar com generosa compaixão para o passado, onde só lhe parecia possível encontrar precários vislumbres das verdades mais atuais da ciência positiva. Houvesse êle meditado sôbre a questão, com maiores conhecimentos, e, por certo, teria reconhecido que, no concernente ao Direito, a Escola Histórica se antecipara a Auguro Comte, na luta contra as abstrações jusnaturalistas, assim como por seu historicismo empírico, tão rudemente criticado por Hegel. ${ }^{23}$

(22) Chega a causar pasmo que nos apresente, por exemplo, DESCARTES como "jurisconsulto notável (sic) e matemático distintíssimo" (op. cit., póág. 27), ou, sem o maior temor, se refira às “inanes especulações de Sócrates e Platão" (pág. 58).

(23) Foi, aliás, o próprio A. CoMte quem viu na Escola Histórica um sinal de reação à Metafísica na Alemanha, no seu Cours de Philosophie positive, 1, L. 47, "in fine" Sôbre êste ponto, v. MiguEL ReAle - Fundamentos do Direito, São Paulo, 1940, págs. 53 e segs. 
Não deixa, porém de ser significativo o fato de ALBerto SALEs não se sentir prêso a qualquer doutrina: no seu escrito, sucedem-se invocações de A. Comte, Spencer, Littré, Gustavo le Bon, Lastarria e Tobias Barreto. A referência ao mestre de Recife é entusiástica, mostrando como as pregações do ardoroso sergipano haviam repercutido profundamente no meio paulista.

Apesar das apontadas falhas de compreensão histórica na invocação das teorias, mister é reconhecer que no refierido ensaio de Alberto Sales algumas páginas sobresaem, notadamente as que põem em relêvo a relatividade e a positividade do Direito, ao acentuar, com apoio em ToBias, ser o Direito "um produto histórico da cultura humana", "um fenômeno puramente histórico, consequência imediata da evolução geral da humanidade e, portanto, revestida essencialmente do caráter da positividade", a qual é, assim, vista como "um dos característicos essenciais do Direito". 24

Quanto à sua concepção do Direito, não deixa de ser curiosa e paradoxal, como expressão de um individualismo darwínico, naturalista e frio, válido do apoio de pretensas leis universais do cosmos.

Primeiramente, inspirando-se em Lastarria, - o publicista chileno que, no concernente à problemática jurídica, acabara numa tentativa de conciliação entre o organicismo ético de Krause e as teorias sociológicas de A. Comte, e H. Spencer, - afirma Alberto Sales que o Direito obedece a "lei geral do condicionamento social", bem como ao princípio correlato da cooperação social, depen-

e IcILIo VANNI - I giuristi della scuola storica di Germania nella storia della Sociologia e della Filosofia positiva, in "Saggi di Filosofia sociale e giuridica”, Bolonha, 1906, págs. 230 e segs.

(24) Registre-se, por conseguinte, a repercussão em São Paulo do culturalismo jurídico da Escola de Recife, culturalismo de caráter naturalista e empírico, como se pode ver em meu livro Horizontes do Direito e da História, São Paulo, 1957, pág. 225 e segs. 
dendo dos sentimentos altruistas que estreitam e fortificam progressivamente as relações individuais. "Vê-se, pois, escreve êle, resumindo o pensamento de LASTARria, que na grande obra de cooperação social, procura cada individuo, na medida de suas fôrças e de harmonia com suas aptidões particulares, concorrer eficazmente para a realização do bem comum, ao mesmo tempo que não abandona o seu bem estar particular, subordinando-se, contudo, ao condicionamento geral de tôdas as atividades parciais, ou a uma mútua dependência entre os seus semelhantes, como único meio de chegar à obtenção do fim social". ${ }^{25}$

o Direito, por conseguinte, consubstanciando no organismo social um conjunto de relações condicionais, representa um ponto de convergência, que serve de objetivo comum superador "do processo contínuo de diferenciação, que se funda, não sòmente na diversidade das aptidões, como ainda na lei geral de divisão do trabalho". ${ }^{26}$

Daí concluir Alberto Sales que, na gênese do Direito, operam múltiplos fatôres inter-relacionados, como o interêsse, o costume, a religião, a moral, e a opinião pública. Antecipando-se, de certa forma, a Duguit, mas inspirado na doutrina de Krause, empresta Alberto Sales a maior importância à opinião, "o mais enérgico fator do Direito", ao ponto de escrever: "Desde que a necessidade social se encarna na opinião e apodera-se da consciência coletiva, nada mais the resta para entrar no quadro geral do Direito do que a sanção dos poderes públicos". ${ }^{27}$

(25) Op. cit., pág. 70 - Cfr. LAstarria - Leçons de politique positive, trad. E. DE Rrvière, Paris, 1879, págs. 80-91 e passim.

(26) Ibidem, pág. 69 - Cfr. Lastarria, op. cit., pág. 89.

(27) Ibidem, pág. 145. Note-se, neste, como nos demais pontos, a solução eclética preferida por nossos positivistas no campo do Direito, dando feição sociológica ao "racionalismo harmônico" de KRAUSE, fato êste também observável na cultura ibérica em geral, com repercussões tanto no Direito como na Política.

$3-2^{\circ}-$ F. D. 
Eis aí afirmado que o Direito, como "condição necessária de vida", preexiste ao Estado, mas só se torna verdadeiramente Direito depois que o Estado, de maneira complementar, lhe reconhece a necessidade. É a razão pela qual êle refuta a definição de JHERING, livremente traduzida e preconizada por Tobias Barreto ("Direito é o complexo das condições existenciais da sociedade, asseguradas pelo poder público"), asseverando: "O Direito não pode ser assegurado pelo poder público; é simplesmente uma função do poder público. Para que o Direito fôsse assegurado pelo Estado, seria indispensável que êste, como um centro de autoridade, entrasse em conflito com a própria sociedade. $O$ poder público não assegura, não garante condição alguma de existência, quer ao indivíduo, quer à sociedade; apenas regulamenta, sistematiza, coordena, disciplina essas condições, que aparecem naturalmente, espontâneamente, e independentemente de sua intervenção. $O$ Direito não é um complexo de garantias, mas sim um sistema de equilíbrio". 28

Se o nosso Autor tivesse sabido explorar êsse veio de idéias, correlacionando o conceito de Direito, como função do Estado, com os de condicionamento e cooperação sociais, talvez tivesse logrado descortinar algo do solidarismo jurídico de Dugurt, ou da teoria da socialidade, em contraposição à da estatalidade do Direito.

Não só lhe faltou fôlego para tanto, como o seu espírito, prêso às amarras dos mitos científico-filosóficos da época, viu-se às voltas com a dificuldade de como conciliar o ideal ético da cooperação altruista com a lei geral da luta pela vida, a qual, "auxiliada eficazmente pela seleção

(28) Op. cit., pág. 110. Como veremos ao tratar de Pedro Lessa, para JHERING o Direito não é um "conjunto de condições de vida", mas antes a forma coercitiva de garantia das condições de vida na sociedade. A tradução de TOBIAS BARRETo pode dar lugar a uma interpretação equívoca do conceito de JHERING, o qual acentua a estatalidade, e não a socialidade do Direito. 
natural e sexual, manifesta-se no domínio inteiro da criação". 29

Êle não vacila um só instante: se é lei do cosmos o sacrifício dos mais débeis; se os antagonismos e as guerras são inevitáveis, e, além do mais, fatôres do aperfeiçoamento e crescimento da espécie, pela sobrevivência dos mais aptos, "para o desenvolvimento expontâneo das próprias fôrças civilizadoras", mister é que o Direito não seja transformado em garantia dos mais fracos. A definição de Jhering afigura-se-lhe, por conseguinte, "anti-científica e incompleta", pois, "o Direito deve deixar que se opere livremente o processo natural e constante da eliminação, em vez de constituir-se elemento perturbador da economia social". 30

Logo, cooperação social, mas de modo que prevaleçam os mais aptos. Uma espécie de solidarismo aristocrático, que faz lembrar NiETzsche, que tão forte tributo pagou a DARWIN em certo momento de sua poderosa compreensão do homem e da sociedade; e, mais remotamente, evoca a dura lição do sofista Trasímaco: "Justo é o que favorece ao mais forte". 31

8 - Há, ainda, no ensaio de Alberto Sales, um ponto que nos interessa: é a posição por êle assumida perante a Jurisprudência e as críticas formuladas por PEREIRA BARRETo, quase dez anos antes.

É na conclusão do seu ensaio, ao elaborar uma "síntese geral", que põe o problema da validade ou significado histórico da Ciência do Direito.

(29) Ibidem, pág. 111.

(30) Ibidem, págs. 119 e seg.

(31) Sôbre êsse aspecto das teorias de NiETZsche e dos sofistas, v. Miguel REALE - Horizontes do Direito e da História, São Paulo, 1956, págs. 187 e segs; Atualidades de um mundo antigo, Rio de Janeiro, 1935, págs. 138 e segs. 
A seu ver, as afirmações de Pereira Barreto "não parecem razoáveis, e nem tão pouco de harmonia com os princípios gerais da Filosofia positiva". ${ }^{32}$ Concorda em que "os legistas, para o futuro, serão obrigados irrevogàvelmente a ceder a cena ao sacerdócio positivo, da mesma maneira que o sacerdócio pagão a cedeu ao cristianismo e êste aos legistas", 33 mas, se admite a transitoriedade histórica dos órgãos, exclui a possibilidade de extinguir-se a funçâo do Direito. Como sistema de equilíbrio de fôrças individuais, o Direito é tão imprescindível ao organismo social como o sistema nervoso ao organismo animal, e "em vez de ser considerado como um poder ou uma faculdade, só pode ser interpretado cientificamente como uma funçẫo, como um fenômeno puramente dinâmico que encontra no Estado o seu órgão especial". ${ }^{34}$

E como todo positivista, reitera a convicção de que, um dia, "o elemento coercitivo, que ainda é a única fonte de autoridade, do prestígio e da fôrça da legislação, tende, contudo, a desaparecer progressivamente", de maneira que a garantia da fôrça material venha a ser substituída "pela uniformidade de opiniões e pelo prestígio das verdades demonstráveis". ${ }^{35}$

9 - Se Alberto Sales tenta situar a problemática jurídica no plano filosófico, já a orientação do Senador Paulo Egydio se desenvolve nos domínios da Sociologia, da qual foi um dos propugnadores mais ardorosos. Poucas pessoas sabem que, por sua iniciativa, na última década da passada centúria, se constituiu o Instituto Sociológico de São Paulo, que despertou, a princípio, grande interêsse entre os intelectuais da época, para logo depois sofrer da doença congênita da indiferença que parece corroer os organismos

(32) Ibidem, pág. 235.

(33) Ibidem, pág. 254.

(34) Ibidem, pág. 258.

(35) Ibidem, pág. 260. 
culturais dêste País, quando uma energia excepcional não os preserva do aniquilamento. ${ }^{36}$

A Paulo Egyoro devemos os primeiros estudos paulistas de Sociologia geral, que valeram como um chamado para o que se escrevera na Europa depois de A. Comte, desde Roberty a Spencer, Stuart Mill e Th. Huxley, de René Worms a Espinas, Fouillée, Gustavo le Bon, Gabriel TARde e Novicow, para não se falar de juristas-filósofos italianos de formação sociológica como Cimbali, Carle, ou Cogliolo e Fragapane.

Informação atualizada e razoável senso crítico distinguem a obra de Paulo Egydio, dando-lhe sinal de maturidade, inclusive por não se escravizar a setorizações aparentes: "A doutrina comteana, a doutrina spenceriana, a doutrina darwínica, pondera êle com argúcia, feita abstração de suas diferenças, formam três ramos de uma mesma árvore - a grande doutrina positiva. ${ }^{37}$

Na sua opinião a Jurisprudência só pode lograr dignidade científica como parte da Sociologia. É claro, acrescenta, que tal assertiva não pode soar de bom grado aos ouvidos dos juristas, orgulhosos da antiguidade de seus estudos, e convictos de representarem êstes "um conhecimento científico perfeitamente constituído, sobretudo em alguns de seus ramos".

(36) Para se aquilatar do interêsse pela Sociologia bastará recordar que PAULo EGYDIo dedica o trabalho intitulado Contribuição para a história filosófica da Sociologia, São Paulo, 1899, aos distintos colegas que assistiram a seu curso, entre os quais figuraram AlbERTo Seabra, Reynaldo Porchat, Afonso Celso garcia, Manoel Viotti, Rafael Sampaio e Amadeu Amaral.

Além dessa conferência, a que JoÃo CRUz COSTA faz ligeira menção em uma nota de sua "Contribuição à história das idéias no Brasil, São Paulo, 1956, pág. 389, escreveu um folheto Do estudo da sociologia como base do estudo de Direito, São Paulo, 1898, e, em 1896, reuniu em um tômo os seus Ensáios sôbre algumas questões de Direito e de Economia Política, que é a sua obra capital.

(37) Ensáios - cit. pág. 26. 
Lembra, a propósito, a polêmica travada na Itália entre juristas tradicionais e da nova Éscola, aquêles reivindicando, como Fulcr, a autonomia da Ciência do Direito, e os segundos sustentando, conforme sintese de ColAJannI, que a Ciência que estuda o Direito (uma das manifestações do organismo social) só pode ser fundada na Ciência que estuda a söciedade.

Bem a par dos últimos estudos sôbre a matéria, já em 1898, Paulo Egydio se referia a conceitos de Fragapane, através de uma nota bibliográfica de RAUl DE LA Grasserie ao primeiro volume de "Objeto e limites da Filosofia do Direito”, editado em 1897.

Fragapane, autor, no dizer de Del Vecchio, do positivismo mais rigoroso e intransigente, empenhado numa pura fenomenologia do Direito mediante pesquisa genético-evolutiva ${ }^{38}$ via, na síntese parcial instituída pelo Direito, como nas demais sínteses da Moral, da Política ou da Economia, “dados preparatórios, por meio dos quais a Sociologia, comparando-os e classificando-os, descobre grandes relações necessárias e constantes, grandes leis gerais e simples, para construir uma síntese mais alta, a vasta síntese social, seu último e supremo objetivo" 39

Tão convencido estava o estudioso paulista dessa tese do sociologismo jurídico ${ }^{40}$ que não titubeava em atribuir mero valor histórico à resistência oposta pelos juristas ciosos da irredutibilidade da Jurisprudência à Sociologia. A seu ver, é "desta ciência que as regras jurídicas devem deduzir a sua legitimidade e o Direito as suas bases racionais". ${ }^{41}$

(38) DeL Vecchro - Lezioni di Filosofia del diritto, x ed., Roma 1958, pág. 110.

(39) v. PaUlo EgYdio - Contribuição para a história filosófica da Sociologia, cit. págs. 19 a 22.

(40) v. Miguel Reale — Filosofia do Direito, 2. a ed., São Paulo, 1957, págs. 403 e segs.

(41) Paulo Egydio - Do estudo da Sociologia como base do Direito, 1898 , pág. 4 . 
Todo um programa de elucidação sociológica é traçado sob êsse prisma, capaz de propiciar ao Direito "a descoberta da lei da justiça e da fórmula científica que a traduza; a decomposição desta fórmula em outras menos gerais que possam reger os infinitos casos da vida relacional dos homens, de modo que tôdas as fôrças sociais não se aniquilem e perturbem" 42

Não se podia ser mais otimista quanto às possibilidades da Sociologia de reduzir a fórmulas científicas a lei da Justiça, de maneira tal que "o legislador-jurista, inteligente e sòlidamente versado nos princípios da Sociologia, poderá vasar as fórmulas legais em soluções tão práticas quão científicas" como transunto fiel do espírito social, e, dêsse modo, "realizarão o govêrno da sociedade dirigida pelos ditames da sabedoria" 43

E concluía prevendo (oh! o perigo das previsões sociais!) uma revolução profunda no espírito da classe legiferante: "A crença na necessidade de se multiplicarem as leis ,escrevia singelamente, será para sempre proscrita e triunfará a crença contrária, da necessidade de se legislar o mínimo possivel" 44

A Sociologia, no entanto, não representa apenas "a base inicial dos estudos jurídicos", mas também a sua cúpula, fornecendo "a explicação filosófica das instituições e das regras que o espírito social descobre e aperfeiçoa para dirigirem a atividade das unidades humanas" 45

Tudo somado, Filosofia e Direito, reduzem-se à Sociologia, como ciência suprema, "alma mater" do espírito humano.

(42) Do estudo da Sociologia como base do Direito, cit., pág. 9. Cfr., ainda, pág. 27, sôbre a "subordinação das verdades e proposições jurídicas às verdades e proposições da Sociologia"

(43) Op. cit., pág. 13.

(44) Op. cit., pág. 14.

(45) Op. cit., pág. 30 . 
Sociologismo jurídico integral é, como se vê, o exposto por Paulo Egydio, em contraste com o sociologismo prudente que, pela mesma época, Pedro Lessa já vinha expondo na Faculdade de Direito de São Paulo.

10 - A terceira personalidade que nos cabe evocar, nesta tentativa de reviver o espírito de uma época, é a de um dos maiores mestres brasileiros de Direito Processual, JoÃo MonteIro, cuja oḅra ainda hoje vive nas cátedras e no fôro, o que bastaria para atestar a sua valia, ao lado da de JoÃo Mendes Júnior.

Jurista elevado ao plano das idéias gerais, procurando estabelecer harmonia entre suas convicções filosóficas e o tecnicismo de sua disciplina, seguiu êle caminho diverso em seu roteiro mental, dando mais justo valor às contribuições da Escola Histórica ou de JHERING na edificação objetiva do Direito, sem olvidar o que de específico e próprio existe na Jurisprudência.

Também êle compartilha das teses fundamentais do evolucionismo spenceriano, assim como do "espírito positivo" de seu tempo, não vendo antagonismo entre a lei darwinística da seleção natural e a do transformismo indefinito de Spencer. ${ }^{46}$

Não tenho em vista apreciar aqui os méritos de João Monteiro à luz da ciência jurídica de seu tempo, ou das diretrizes posteriores que deram ao Direito processual verdadeira dignidade científica, mas apenas, em traços rápidos, demonstrar, com o seu exemplo, quanto andava imbuída de cientificismo a nova geração de professôres no início da era republicana.

No seu caso, a preocupação científica, o desejo de ajustar o Direito à temática positiva, chega a extremos de

(46) V. a "Introdução" ’̀ Teoria do Processo Civil e Comercial publicada em 1893, no fascículo inaugural da "Revista da Faculdade de Direito" de São Paulo, págs. 9 e segs. Cfr. do mesmo autor Teoria do Processo Civil e Comercial, São Paulo, 1912, 3. ${ }^{\natural}$ ed. pág. 88. 
exageros terminológicos, como o revela esta conhecida passagem de seus escritos:

“Assim como a fisiologia é o estudo do mecanismo humano em seu estado de integridade ou de saúde, assim também podemos denominar ciência da fisiologia jurídica o estudo do direito em sua abstração legislativa; e bem como patologia'é o estudo das desordens ocorridas no organismo humano ou das moléstias, assim também a patologia jurídica será o estudo das violações das relações de direito. E como a terapêutica é o "complemento da patologia, faz-se ainda o estudo dos remédios contra aquelas desordens ou moléstias; e então, bem como a terapêutica é a parte da medicina que tem por objeto o curativo das moléstias, assim a terapêutica jurídica será o estudo dos meios restabelecedores do equilíbrio das relações de direito". ${ }^{47}$

Abstração feita dêsse jôgo de metáforas que mereceu o reparo crítico de JoÃo Mendes Júnior, ${ }^{48}$ é inegável que o permanente amor aos fatos exerceu papel relevante em suas construções jurídicas, preservando-o de certos formalismos, em cujo vício incorreu, às vêzes, o seu ilustre opositor, mestre de Prática Forense. A participação às idéias novas permitiu-lhe abrir naturalmente os quadros da doutrina luso-brasileira ao sôpro vivificante das correntes do pensamento contemporâneo, não sendo dos menores o mérito de ter enxertado os ensinamentos da novel processualista alemã e itálica no velho e robusto tronco da praxística lusa.

Conhecedor cuidadoso do Direito pátrio, JoÃo MoNTEIRo não se contentava com os horizontes da positividade jurídica nacional, pregando, como realidade em futuro mais ou menos próximo, a cosmopolização do Direito. ${ }^{49}$

(47) Loc. cit., pág. 19.

(48) v. Revista da Fac. de Direito, vol. vII, 1899, págs. 343 e segs.

(49) JoÃo Monteiro - Cosmópolis do Direito, na "Rev. da Fac. de Direito", vol. III, 1895, págs. 144 e segs. 
Espírito cosmopolita, sob o influxo de múltiplas fontes de pensamento, - o que era deveras excepcional na época, - Joño Monteiro levou, até às raias da utopia, o ideal da universalização do Direito, das línguas, das civilizações.

Não o fazia, entretanto, fundado jusnaturalisticamente na unidade essencial do homem, mas com apêlo a "verdades científicas", escrevendo: "Os fenômenos de generalização e complexidade dão ainda lugar ao seguinte princípio sociológico, de transcendental importância para a nossa tese: quanto mais os institutos jurídicos se generalizam e mais complexos se tornam, mais se reduz a quantidade das regras de direito, e sua morfologia menos complicada se apresenta na euremática judiciária; o que equivale prever uma época em que, estreitados todos os Estados e povos pelos laços da política e da economia industrial em tôdas as suas infinitas ramificações, chegue o direito, que é o modo de ser humano de todos os vínculos sociais, a tal grau de generalização e complexidade, que, reduzido a poucas regras, tantas quantas bastam para a indicação dos pontos culminantes das heterogenizações sociais, se torne universal"

Ninguém em São Paulo foi tăo rigorosamente fiel à "concepção naturalista do Direito" como JoÃo Monteiro. o que ressalta ao criticar o providencialismo de Laurent que subordinava a vida das Nações a Deus, "mística entidade que não acha lugar no quadro das ciências sociológicas", e que deve ser substituída pelo conceito de natureza, "a ação motriz do mundo orgânico e inorgânico", consoante "a lição correta e intransigente do naturalismo histórico". ${ }^{50}$

(50) Universalização do Direito, Cosmópolis do Direito, Unidade do Direito, São Paulo, 1906, pág. 40, nota 37 e pág. 22, nota 18.

Não se pense, todavia, que JoÃo MonTeIRo fôsse infenso à Metafísica. Parecia-lhe, ao contrário, e com tôda a razão, que tanto na obra de ComTe, como na de SPENCER, para lembrar a expressão 
Pedro Lessa e uma nova geração de professôres

11 - Pedro Lessa, colega de turma de Alberto Sales e seu companheiro de jornalismo acadêmico, ${ }^{51}$ ao ingressar em 1881 no corpo docente da Faculdade de Direito de São Paulo, como professor substituto, não se pode dizer tenha encontrado em situação brilhante os padrões de nosso ensino jurídico. Pelo contrário. Às críticas acerbas de Pereira Barreto faziam côro outras, que não se comprometiam em profecias aziagas, mas, nem por isto, se mostravam menos causticantes. Aqui, como no Recife, proclamava o irreverente ToBias BARreto, a ignorância era "ensinada com método e ainda mais metòdicamente aprendida"; e, apesar da acritude, Alberto Sales endossava a crítica, acrescentando: "uma corporação científica, que vive das migalhas do passado e que se obstina em contrariar os progressos da mentalidade humana, por uma espécie de odium theologicum, é uma instituição que se formaliza e que só pode valer, quando muito, para temas sentimentais de recordações históricas". ${ }^{52}$

de Cogliolo, por êle usada, havia "della Metafísica bella e buona". (Cs. Teuria do processo, cit., vol. I, pág. 88).

(51) Formaram-se ambos em 1883, militando juntos em $A$ República e O Federalista (v. SPENCER VAMPRÈ, op. cit., t. II, pág. 424) assim como em $A$ Luta, publicação "positivista no tom usando tanto o calendário gregoriano como o positivista..." (v. GeORGE C. A. BOEHRER - op. cit., pág. 97). Como se vê, dois espíritos originàriamente irmanados no ideal republicano e em cabedal comum de teorias.

$\mathrm{Na}$ história do republicanismo em São Paulo, - e, como se sabe, foi aqui que o movimento alcançou maior densidade e estrutura, - coube ao positivismo papel relevante. Refiro-me, porém, ao "positivismo" lato senso, como corrente global de idéias e de valores, e não ao positivismo sectário que representou um episódio fugace e marginal na vida republicana paulista.

$$
\text { Alberto SAles - op. cit., pág. } 249 .
$$


Até mesmo professôres de formação tradicional, nos moldes coimbrãos, como Vicente Mamede, na Memória Histórica para o ano de 1882, já profligara o sistema de ensino em vigor, que, de alguma forma “concita os estudantes à vadiação, torna-se cúmplice dêsse delito, da desídia escolástica, coopera numa fábrica de ignorantes, para, no fim do ano, os entregar, como vítimas apropriadas, ao rigor dos algozes, que os têm de imolar, pela culpa, que, se é dêles, também o é do regime sob que vivem". ${ }^{53}$

Não se pode, por conseguinte, acoimar de injusta a crítica feita por Rur Barbosa ao nosso ensino superior, no memorável Parecer apresentado à Câmara do Império em 1882, vasado segundo os princípios da Filosofia positiva, como já tive ocasião de demonstrar. Foram palavras rudes as de Ruy, mas há momentos em que é mister a verdade nua e crua: "fazemos justiça aos lentes de mérito, que as nossas Academias contêm; mas o ensino em geral tem descido de um modo incalculável. Parece impossível baixar mais". ${ }^{54}$

(53) v. VAMPRÈ - Memórias para a história da Academia de São Paulo, cit., vol. II, págs. 447 e segs.

(54) A propósito de uma lição de Direito Romano de SÁ E BENevides, transcrita nos Anexos ao citado Parecer, Cfr. Obras Completas de RUI, vol. IX, 1882, tomo I, 307, nota 1.

A reação naturalista contra o insonso ecletismo dominante em certos círculos, quando se fundiam SANTo Tomás, Cousin, Tiberghien e o Syllabus, na mais alarmante carência de senso crítico, foi inegavelmente benéfica, inclusive para a Filosofia tradicional, que passou a rever as suas posições, em busca de maior fidelidade ao ensinamento escolástico. Será bastante cotejar os escritos de SÁ E Benevides com os de JoÃo MENDES JÚNIOR, por exemplo, para se reconhecer a procedência dêste nosso acêrto.

Sôbre os pressupostos filosóficos em que se fundava RUI, adepto do positivismo heterodoxo na época imperial, v. meu ensáio "Posiçảo de Rui Barbosa no mundo da Filosofia", em Horizontes do Direito e da História, São Paulo, 1956, págs. 244 e segs. 
12 - Pedho Lessa já não se mostra tão rigoroso, revelando mais confiança no soerguimento da Academia: "Sem compartir o exagero de alguns, escrevia êle na $M e$ mória Histórica para 1888, tendo antes a veleidade de enxergar simples estacionamento, talvez precursor de um novo ciclo de atividade, onde se assinala a mais contristadora decadência, não posso, todavia, em relação ao período de que me ocupo, deixar em silêncio a permanência do fato. " 55

Essa preferência pelo meio têrmo, pela moderação doutrinária, viria a constituir quase uma constante teórica num homem que, no plano da praxis, desde a Faculdade de Direito até ao Supremo Tribunal Federal, não se fêz notar pela mansuetude, mas antes pelo gôsto dos contrastes e por forte dose de paixão.

Deve-se frizar, aliás, que se positivaram as suas esperanças de dias melhores para as Arcadas, graças à alteração profunda por que passou, em menos de um lustro, o corpo docente, com o advento à cátedra de espíritos tocados pelas idéias da época, ou convencidos da necessidade de dar novo alento aos valores tradicionais. Bastará lembrar que, ao lado de Joño Monteiro, catedrático desde 1883, veio integrar a Congregação uma plêiade de mestres eminentes, como Dino Bueno e Brasílio Maghado em 1890; Pedro Lessa, João Mendes de Almeida Júnior e José Luís de Almeida Nogueira, em 1891.

Aos poucos, em tôdas as cátedras, como já assinalado por Reynaldo Porchat, ao analisar o pensamento filosófico no primeiro século da Academia, ${ }^{56}$ passaram a prevalecer

(55) Apud VAMPRÈ - op. cit., vol. II, pág. 517.

(56) Revista da Faculdade de Direito de 1928, vol. XxIv, págs. 253 e segs. Sôbre o contraste entre o tradicionalismo de JoÃo Mendes Júnior e o cientificismo de PEDro Lessa, dispenso-me aqui de fazer maiores considerações, pedindo vênia para lembrar ao leitor interessado o meu estudo Escolástica e praxismo na teoria do Direito 
as diretrizes metodológicas da Filosofia positiva, a começar pelo Direito Criminal, através dos estudos de Antropologia e Sociologia.

Poder-se-á dizer que o positivismo, posto em confronto com a densidade especulativa do idealismo post-kantiano, que se alteara às culminâncias de um Schelling, de um Fichte ou de um Hegel, terá representado um momento de depauperamento filosófico, por reduzir-se a Filosofia a uma "ancilla scientiarum", mas já foi justamente observado por Teófilo Cavalcanti Filho, que, válida e aceitável aquela tese para o mundo europeu, não pode a mesma aprevalecer no Brasil, onde, com tôdas as suas deficiências, a Filosofia só firmou decididamente os seus primeiros passos à sombra de Augusto Compe e de Herbert Spencer. Só então surge entre nós um complexo de idéias e de convicções norteando de maneira efetiva a tôda uma geração, da qual Pedro Lessa é, sem dúvida, uma das figuras mais representativas.

\section{IV}

\section{Posição de Pedro Lessa perante o Positivismo e a Metafísica}

13 - Comungava o catedrático de Filosofia de Direito, não há dúvida, com as idéias mestras do naturalismo, mas sem deixar de tomar posição perante as suas diversas ramificações, segundo pendores pessoais e, às vêzes, com certa originalidade.

Essa independência na valorização das teorias, sem demasiado apêgo aos "idola tribus", êle a revela desde o seu primeiro escrito de maior tômo, a longa Introdução que redigiu para a tradução brasileira da História da Civi-

de João Mendes Junior, no volume desta revista destinada à comemoração do seu centenário (1956). 
lização da Inglaterra, de Buckle, também publicada em separata sob o título: E a história uma ciência? ${ }^{57}$

O mencionado ensaio de Pedro Lessa, salvo engano, representa o primeiro trabalho publicado no Brasil sôbre Filosofia da História, refletindo os modos de pensar dominantes na historiografia naturalista do fim do século. Se é sumária e superficial a apreciação que dedica, por exemplo, à obra de Machiavelli, de Vico ou de Hegel, não se afasta muito dos modelos e estilos então em voga. Não se lhe pode recusar, todavia, o mérito de ter redigido uma síntese valiosa das questões essenciais suscitadas pelo programa de se converter a História em uma ciência rigorosamente positiva, "ao nível das que se ocupam com a natureza".

Note-se que, no citado estudo, assume êle posição crítica perante A. Comte, cuja lei dos três estados repele, invocando a favor de sua opinião textos do próprio Cours de philosophie positive, para chegar à conclusão de que "a reflexão sôbre os fatos históricos, desde a mais alta antiguidade, nos convence de que as idéias teológicas, metafísicas e positivas, têm sempre coexistido. As três ordens de concepção não assinalam períodos sucessivos do pensamento humano, porém modalidades sincrônicas, posto que diversas, direções várias, posto que coevas, das idéias que formamos sôbre os fatos." 58

Daí a conclusão de que as concepções teológicas e metafísicas subsistem perfeitamente ao lado das verdades científicas, tendo razão SPENcer quando diz que "a religião e a ciência são necessàriamente correlativas", representando "dois modos antitéticos da consciência, que não podem existir separados: são os polos, negativo e positivo, do pensamento, um dos quais não pode crescer sem inten-

(57) V. BuckLe - História da Civilização na Inglaterra, trad. de A. J. A. Malchert, São Paulo, 1900, págs. III usque cviII; $E$ a história uma ciência, data supra.

(58) Introdução, cit., pág. xxxrv. 
sidade sem aumentar a do outro. A certeza da existência do poder insondável tem sido sempre o fim que a inteligência há procurado atingir". ${ }^{59}$

A Metafísica, conclui Pedro Lessa, não se ajusta aos processos científicos, mas o estudo da natureza do espírito humano nos convence de que "a nossa inteligência nunca poderá resignar-se à abstenção de quaisquer cogitações sôbre as causas primárias e as causas finais".

"Tudo nos leva a crer, - prossegue êle, firmando ponto de vista a que se manterá fiel em seus escritos posteriores, que êsse conjunto de especulações sôbre os seres, que não podemos conhecer pelos processos científicos, e especialmente sôbre a Causa última, que Augusto Coмte reuniu sob a denominação de Metafísica, há de ser perpètuamente uma fonte inexaurivel de consolações ou de esperanças, de incertezas ou de angústias, para esta miserável e torturada impotência de espírito humano". ${ }^{60}$

O Incognoscível de Spencer, o Absoluto, que não se põe como problema a ser cientificamente resolvido, é objeto de cogitação inevitável, correspondendo a uma exigência conatural ao espírito humano, dada a sua precariedade e deficiência: Metafísica e Religião são, dêsse modo, realidades inamovíveis, por mais que se apure e se alargue o campo das ciências positivas.

"Mas 'se a Religião é necessária, advertia êle, polemizando com os partidários ardorosos do comtismo, mante-

(59) Ibidem, com remissão a SPENCER, Les Premiers Principes, trad. de Cazelles, 8. ${ }^{\text {a }}$ edição, pánss. 94 e 95.

(60) Op. cit., pág. xxxv. Em 1896, PEDro Lessa já escrevera: "Quanto à Metafísica, que só o acanhado espírito de seita repele, o que a constitui é um conjunto de especulações sôbre os seres e os fenômenos que não podemos conhecer cientificamente" (Rev. Fac. Direito, vol. Iv, pág. 13). É o que ainda repete em 1916, na 2. ${ }^{\mathrm{a}}$ ed. de seus Estudos de Filosofia do Direito, pág. 24, colocando, ao lado da Metafísica, vista comó conjunto de especulações sôbre o incognoscível, a Religião, cujo objeto é a fé, e a Ciência, cujo objeto é a explicação. 
nhamos a que foi abraçada pela imensa maioria da Nação, a que a tem consolado nas angústias e nas dores.. " 61

Manifesto, é, nessa atitude, o drama íntimo que atormentou a tantos homens da geração do fim de século, o contraste ou a antinomia entre a Religião e a Ciência, aquela concebida como o resto inexorável das humanas deficiências, a sombra do mistério a circundar o mundo dos problemas. Nem faltou, certa feita, a Pedro Lessa o recurso ao sorriso cético de RENAN, invocando, embora em atitude transitória, a desconsolada lição de EÇA DE QUEIRoz: “. .depois de ter arrastado penosamente os meus discípulos pelos inúmeros corredores do vasto e complicadíssimo labirinto dos sistemas, durante cêrca de quinze anos (mais cinco do que o "Fausto" de GoEthe), cheguei ao resultado, precisamente miserável, de adotar, como um desolador transunto da verdade, o conceito de "Fradique Mendes" em uma de suas "Cartas" deliciosas: "um sistema filosófico é mais uma conjetura para se juntar a um imenso montão de conjeturas". ${ }^{62}$

Eis aí quão longe estava o antigo catedrático de Filosofia do Direito do fanatismo científico-religioso do "Apostolado Positivista", cuja existência ainda parece a alguns ter sido o cerne de nossos valores mentais, quando, na realidade, representou o ponto de vista de reduzida minoria, divorciada das convicções dominantes no País, firmadas em um naturalismo aberto a múltiplas influências, inclusive à do "criticismo de Kant", enxertado curiosamente por Tobias Barreto e Sílvio Romero no monismo ou no evolucionismo.

A independência de Pedro Lessa perante A. Comte repete-se em relação a outros pensadores, mesmo àqueles que mais admira, como Spencer e Stuart Mrll. De temperamento polêmico por natureza, ama acima de tudo o

(61) Discursos e conferencias, São Paulo, 1916, pág. 21.

(62) PeDRo Lessa - Discursos e Conferências - São Paulo, 1916, pág. 60 .

$4-2^{\circ}-$ F. D. 
debate das idéias. Vislumbra-se mesmo em algumas de suas exposições o jôgo dialético do bacharel, sopesando os prós e os contras das teorias, como se fôra um Juiz obrigatòriamente cingido ao dever de optar por uma solução, acolhendo ou rejeitando a demanda. E que se nota por exemplo, nas críticas movidas às doutrinas filosóficojurídicas de Kant, Savigny ou Jhering. ${ }^{63}$

Sob êsse prisma, talvez fôsse possível apontá-lo, embora sem os exageros de Tobias Barreto e Sílvio Romero, como um representante da mentalidade filosófico-polêmica moldada nas Faculdades de Direito, e caracterizada pela tendência de converter os juízos de valor ou a crítica externa dos sistemas em um ato de aplauso ou de condenação; assim como a dos tempos coloniais sofrera natural deformação pelos estudos escolásticos dos seminários, inclinando os espíritos às sutilezas das distinções formais. Quanto à atitude atual de bom número de nossos estudiosos de Filosofia, talvez se possa caracterizá-la por um desejo mais profundo de diálogo. O diálogo, desde Platão, está na raiz do filosofar, e implica, para ser autêntico, no dever da crítica interna dos sistemas, numa compreensão mais objetiva e serena dos valores adversos. Não que possam desaparecer ou inexistam na Filosofia os contrastes e os conflitos ideológicos (as verrinas de certos neopositivistas, que devotam soberano e frágil desprêzo por tudo o que não se ajuste às suas verdades protocolares, seria um desmentido formal a tal pretensão!) mas é certo que uma orientação diversa tende a prevalecer, infensa ao endeusamento do filósofo da moda, ou ao jugo das "escolas dominantes", com maior respeito, em suma, pelos valores intrínsecos das doutrinas, sem a preocupação de as repelir apaixonadamente ou de as emascular no amálgama comprometedor dos ecletismos.

Voltando, porém, a PEDRo Lessa, mister é assinalar, como um de seus méritos, o propósito de ao menos repen-

(63) v. PEDRo Lessa - Estudos de Filosofia do Direito, 2. ${ }^{\mathrm{a}}$ ed. São Paulo, 1912, págs. 341 e segs.; 377 e segs. e 415 e segs. 
sar o pensado alhures. Releiam-se, por exemplo, as páginas dedicadas a Buckle, a quem não nega encômios, exagerando-lhe até mesmo a importância na historiografia moderna: é uma crítica penetrante, às vêzes irônica, às pretensas leis históricas apontadas pelo escritor inglês.

Assim é que, tendo Buckle pretendido explicar a inexistência de uma civilização brasileira, como a do México e do Perú, em virtude da caudal de nossos rios, da exuberância de nossas florestas, do prodígio dos prados fertilíssimos e da opulentíssima fauna, tudo reduzindo o homem a um pigmeu no meio da riqueza circundante, Pedro Lessa exclama, sarcástico: "nós a lutarmos com os terriveis efeitos das sêcas periódicas, a ouvirmos seguidamente lamentar a devastação das nossas matas e a falta de terras férteis, poucas relativamente à extensão corográfica de nosso território, e com êsses portentosos tesouros ao alcance da mão, e no seio dessa fabulosa feracidade!" 64

E quando Buckle, empolgado pelo individualismo, condena a intervenção do Estado no plano econômico e cultural, reputando-a altamente nociva ao progresso social, - tese que, no fundo, também era a de SPENcER -, o nosso Autor repele com veemência a doutriná da minimização do poder público, tão cara a evolucionistas e positivistas, contrapondo-lhes as tendências socialistas que seis décadas cuidaram de positivar: "Diante das tendências socialistas dominantes em nossa época, e quando o Estado cada vez mais alarga a sua atividade, criando instituições, regulamentando fatos sociais, manifestando, em suma, a sua fôrça impulsora e geradora em assuntos de que antes não cogitavam os governos, a proposição do historiador inglês dispensa uma impugnação fundamentada". ${ }^{65}$

(64) Introdução, cit., pág. Lxv.

(65) Introdução, cit. pág. Lixvil. Não foi só nesse passo que Pedro Lessa revelou seu interêsse e simpatia pelos ideais socialistas. V. o estudo Que é o Socialismo?, na "Rev. da Fac. de Direito", de 
Spenceriano, pois, mas sem conceber a evolução culminando no triunfo individualista; admirador de A. Comte, mas sem admitir a redução do plano da religião ao da ciência; naturalista sim, mas sem divinizar a natureza, ou sentir escrúpulo em usar a palavra Deus, substituída por "natureza naturante" ou quejandas, Pedro Lessa poderá não ter sido um criador, capaz de abrir clareiras novas às especulações filosófica ou filosófico-jurídicas, mas soube fundir em sua personalidade um conjunto de convicções atuais, segundo uma linha dominante de equilíbrio e de coerência.

\section{V}

\section{Direito Natural e Direito Positivo - Ciência do Direito e Dogmática jurídica}

14 - A atitude de Pedro Lessa com referência aos problemas metafísicos já nos faz antever a sua tomada de posição diante do velho e sempre novo tema do Direito Natural.

Embora afirmando a impossibilidade de uma Ciência jurídica divorciada dos fatos sociais e históricos, repugnalhe a solução dada pelo teleologismo hedonístico de

1895 (vol. III), págs. 45-62. Na mesma Revista, em 1900 (vol. viI, pág. 206), ao recapitular os valores do Direito no século que findava, escrevia: "Muitas das aspirações das várias escolas de socialismo pròpriamente dito hão de ser fatalmente (sic) concretizadas em lei. Não há um só homem de coração bem formado, que se não sinta constrangido ao contemplar o doloroso quadro oferecido pelas sociedades atuais com a sua moral mercantil e egoística. O socialismo há de triunfar parcialmente. O seu triunfo é infalível, necessário"'.

Bem distinta, por conseguinte, a sua atitude da de Alberto SAles, também lùcidamente convencido do advento do socialismo, mas visto como uma "desgraça inevitável", embora com a duração dos cataclismos e das convulsões, o que era uma esperança e um consolo para êle, individualista de fé arraigada em convicções spencerianas. (Cfr. Revista do Brasil, cit., vol. 70, págis. 342 e segs.) 
Jhering ou pelo historicismo de Savigny, pois em ambos não haveria lugar para o Direito ideal, nem explicação para a "constante" de certos princípios fundamentais, de natureza bio-ética.

"O filósofo que indutivamente sobe de generalização em generalização, é obrigado a reconhecer que tôdas as legislações, em qualquer país e em qualquer periodo histórico, repousam em princípios fundamentais necessários, sempre os mesmos.

"Neguem, se quiseram, a êsses princípios o qualificativo - jurídicos; digam que há uma lei natural, e não um direito natural, como querem alguns, ${ }^{66}$ afirmem, como pretendem outros, que são princípios sociológicos, que devem ser estudados na Sociologia jurídica, ou na história natural do Direito, lo cierto es que la cosa queda siendo la misma". ${ }^{67}$

(66) Alusão a Tobias BARRETo que se satisfizera com um jôgo de palavras, afirmando não haver Direito Natural, mas uma lei natural do Direito (v. Questões vigentes, Sergipe, 1926, pág. 125).

(67) Pedro Lessa - Estudos de Filosofia do Direito, - 2. ${ }^{a}$ ed. São Paulo, 1916, pág. 36. A referência em castelhano é de Dorado Montero - El Positivismo en la Ciencia juridica y social italiana, pág. 175. Cfr. José Pedro Galvão de Souza - O positivismo Jurídico e o Direito Natural, São Paulo, 1940, págs. 46 e segs., onde a concepção de PEDRo LESSA é apontada como sendo "de caráter biológico, ou melhor, bio-sociológico", ao lado da de SPENCER. Seu conceito de Direito Natural apresenta, porém, pontos de contato com a teoria clássica, como, por exemplo, quando "descobre como fundamento das leis, promulgadas para reger uma sociedade, certas necessidades sociais, decorrentes e inseparáveis da natureza do indíviduo e da sociedade" (Estudos, cit., pág. 56). Um krausista não desdenharia dessa noção.

Lembre-se, outrossim, êste período em que êle proclama a existência de leis jurídicas universais e imutáveis: "Assim, escreve LESSA, ao lado das necessidades comuns a todos os organismos sociais, constantes, permanentes, há outras próprias de cada fase social, o que faz que ao lado dos princípios e das normas jurídicas universais $e$ imutáveis haja instituições variáveis" (Estudos, cit., pág. 469). Tal- 
Afigura-se-lhe absurdo recusar o caráter de "lei natural" a necessidades que são sempre as mesmas, a condições. de vida indispensáveis, a imposições fatais da natureza do indivíduo e da natureza da sociedade, cuja sanção natural é mil vêzes mais grave do que a sanção criada pelos homens. ${ }^{68}$

Impossível seria também reduzir o jurista a um mero seguidor passivo dos processos naturais, pois, no Direito, pondera êle, como em tudo, o ideal se forma péla faculdade que temos de abstrair, de separar mentalmente os defeitos, as imperfeições, as impurezas da realidade: "nas ciências que tệm por objeto o bem, o justo e o belo, a hipótese chama-se ideal, que algumas vêzes não passa de utopia" 69

vez seja preferível, por conseguinte, qualificar de bio-ético, o Direito Natural de PEDro Lessa, consoante expressão empregada, à pág. 37 da mesma obra, para indicar as necessidades constantes que o explicam e legitimam.

(68) Estudos, cit., pág. 47 - Cfr. supra. Essa preocupação de fundamentar o Direito Natural de maneira objetiva, em íntimo liame, com a experiência social e histórica, segundo o que fôra exemplarmenmente elaborado na ampla versão positivista de ROBERTo ARDigò, para quem "a justiça é a fôrça específica do organismo social"; e "o Direito Natural o valor transcendente absoluto da natureza, donde provem" (Cfr. Sociologia, Vol. IV das "Opere Filosofiche", Padua, 1886, págs. 95 e segs. e 157 e segs.) não permite se confunda afoitamente a concepção de PEDRo Lessa com a dos modêlos racionalistas. Bastará comparar o seu conceito com o desenvolvido, anos antes, por ALMeida NoGUEira, nos seguintes têrmos: "Prescrevendo as omissões necessárias para a coexistência social e garantia dos direitos, a lei social absoluta, consequência necessária da natureza moral e física do homem, revelada pela razão, e concretisada pelo poder soberano, apresenta os seguintes caracteres: impõe sòmente obrigações negativas, é coercível, regula as relações de modo a conciliar o direito de cada um com a liberdade alheia. Essa é a concepção fundamental de Rosmini que adotamos." (Ensáios Jurídicos e Sociais, São Paulo, 1873, pág. 67).

(69) Op. cit., pág. 61. 
Cumpre, por conseguinte, distinguir entre ideal e utopia, sendo esta o resultado de uma pura criação do espírito, enquanto aquêle se elabora graças ao conhecimento das leis que regem os agregados humanos. Por isso, lembra a lição de Durisherm, para quem a Sociologia não nos impõe uma atitude passivamente conservadora, mas, ao contrário, alarga-nos o campo de ação graças ao acúmulo de conhecimentos científicos. ${ }^{70}$

15 - Assente essa concepção de Direito Natural e de Direito Ideal, - o primeiro correspondente ao que há de imutável no evolver histórico do "jus"; e o segundo relativo ao desejo de perfectibilidade fundado em leis científicas, - como são concebidos por Pedro Lessa o Direito e as disciplinas que o estudam?

Escusado é dizer que a sua obra assinala completo afastamento das idéias de Pereira Barreto e dos positivistas ortodoxos sôbre o Direito. A sua atitude em relação a êles é mesmo rude, ao proclamar que nada deve diretamente a renovação dos estudos juridicos a Augusto Comte e seus sequazes:

"Foram alguns jurisconsultos contemporâneos, adverte, como D’Aguanno, Cogliolo, Schiattarella, Miraglia, Puglia, Icilio Vanni, e pensadores também de nossa época, como Spencer e Schäfrle, que pela aplicação do método positivo ao estudo da Filosofia do Direito imprimiram nessa doutrina um cunho científico.

"Cumpre observar que a Filosofia do Direito nada deve diretamente a Augusto Comte e a seus vulgarizadores"

"A ignorância do filósofo francês e de seus discípulos em assuntos jurídicos é tão profunda e adiposa, que um dêles não hesitou, resumindo as lições do mestre, em escre-

(70) Op. cit., pág. 154. 
ver o seguinte colossal disparate: "a nova filosofia substitui à discussão vaga dos direitos a determinação rigorosa dos deveres respectivos". ${ }^{71}$

Para o mestre de São Paulo os sectários do positivismo, "alimentando-se e vivendo exclusivamente do ridículo", com pretensão a novos orientadores da humanidade, "para cada instituição jurídica propõem uma reforma disparatada; para cada problema social uma solução irrisória; para cada um dos males da sociedade um remédio absurdo; em meio de cada controvérsia da imprensa diária um novo desconchavo; em resposta a cada idéia boa que se agita, um dislate surpreendente". 72

O certo é que Pedro Lessa se propunha, em contraposição aos "positivistas", demonstrar o caráter científico da Jurisprudência, reagindo, ao mesmo tempo, contra as concepções metafisicas de Krause e de Ahrens, que haviam fundado o saber jurídico apenas em pressupostos racionalistas.

No seu entender, o melhor caminho a trilhar seria estender rigorosamente ao Direito os mesmos processos lógicos, a mesma metodologia empregada nas ciências naturais e nas "ciências sociais e inferiores". Como veremos, tal critério consistia em seguir à risca os ensinamentos de STuart Mill sôbre indução e dedução. É com certa jactância que Pedro Lessa se refere a essa opção metodológica: "adotado e seguido êsse critério, pareceu-me haver descoberto (sic) o meio de, evitando a influência nefasta da excessiva floração das extravagantes idéias filosófico-jurídicas, de que está repleta a literatura jurídica e filosófica, ministrar uma explicação do Direito, de acôrdo com os fatos, cuja observação lhe é único funda-

(71) Cf. “Rev. Fac. Dir.", 1896, vol. Iv, pág. 13.

(72) Discurso proferido em 1896, inserto em Discursos e Conferências, cit., pág. 18. 
mento, conforme aos preceitos da Lógica, e eficaz, satisfatória, no domínio da prática". ${ }^{73}$

Nada julga êle mais indiscutível e fecundo do que o indutivismo científico de MrLl, com a sua discriminação entre a Ciência, fundada em processos indutivos, e a Arte, elaborada segundo inferências dedutivas, a partir dos princípios e leis postos pela primeira.

Fiel a essa distinção, recusa Pedro Lessa categoria científica à Jurisprudência, tal como é tradicionalmente entendida, ou seja, como conjunto de processos interpretativos de textos legais e ordenação sistemática de institutos: não seria mais do que uma Arte, e, menos do que isso, "a explanação de uma Arte". A tal espécie de estudo é que, no seu entender, deve ser reservada a denominação de Dogmática Jurídica. ${ }^{74}$

A verdadeira Ciência do Direito, ao contrário, a que não se desenvolve no fôro, nem nas obras dos juristas técnicos, não é dedutível de preceitos vigentes: só pode ser indutiva, gozando de relativa autonomia no campo comum da Sociologia, à qual compete o conhecimento das leis gerais que ordenam a sociedade. Sem ser mero capítulo da Sociologia, a Ciência do Direito, como cada uma das. ciências sociais, "se consagra ao estudo das leis que regem uma determinada classe de fenômenos, está encerrada em uma esfera limitada, particular, tem um domínio seu. 0 Direito se ocupa das leis, a que estão subordinados os fatos sociais desta determinada classe: as condições de vida $\mathrm{e}$

(73) Estudos, cit. pág. 12.

(74) Sôbre êsse aspecto do pensamento de LESSA, cfr. minha Filosofia do Direito, 2. ${ }^{\text {a }}$ ed., 1957, vol. II, págs. 303 e segs. “A Dogmática Jurídica, asseverava o nosso ilustre predecessor na cátedra, encerra um conjunto de preceitos, formulados para a realização de fins determinados; é a explanação de uma arte. Confundí-la com a Ciência importa desconhecer um dos mais vulgares elementos da Lógica". (sic) - Estudos, cit. pág. 73. 
desenvolvimento da sociedade e do individuo, dependentes da vontade humana, e já garantidas, ou que é necessário o sejam, pela fôrça física do Estado". ${ }^{75}$

Não se pode recusar certa originalidade de propósitos a essa discriminação lessiana entre Ciência e Arte ou Dogmática do Direito, em função da aplicação sucessiva dos métodos indutivo e dedutivo, à maneira de Stuart MrLl, cujos ensinamentos lógicos eram, talvez pela primeira vez, transladados para o campo científico do Direito para distinguir dois tipos de pesquisas: a sociológica e a técnico-jurídica.

Infelizmente, forçoso é reconhecê-lo, Pedro Lessa apenas deixou esboçada a sua teoria, nada de positivo nos dizendo sôbre a natureza real da Ciência Jurídica perante a Sociologia ou a Sociologia Jurídica, denominação já então prevalecente nos estudos, sobretudo desde ANZILоттг. ${ }^{76}$ As poucas páginas, que dedica à matéria, são também imprecisas para a caracterização do que seria "a explanação de uma arte": é possível que, se a sua carreira no Magistério não tivesse sido interrompida pela alta missão de Ministro do Supremo Tribunal, tais aspectos de seu pensamento viessem a ser elaborados, especialmente no que se refere aos problemas complexos suscitados pela noção do Direito como norma técnica ou preceito artístico.

16 — Na realidade, porém, tôda a sua construção estava fundada em dois equívocos, desfeitos pela metodologia científica e pela Filosofia posteriores. O primeiro consistia em confundir, nas pegadas de MiLL, "método científico" com "método indutivo", quando, no dizer de Einstein, "não há método indutivo que nos leve aos con-

(75) Penro Lessa - Estudos, cit., págs. 11 e segs.

(76) Limita-se, por exemplo, a dizer, e de passagem, que, se, "como já se tem afirmado, há uma Sociologia Jurídica, e não uma Ciência autônoma do Direito", trata-se de uma questão "mais de palavras do que de idéias" (Cfr. Estudos, cit., pág. 154 e seg.) 
ceitos fundamentais da Física", devendo ser considerado "o pensamento lógico necessàriamente dedutivo, baseado em conceitos hipotéticos e em axiomas", ${ }^{77}$ razão pela qual se reconhece que o método científico é antes "hipotéticodedutivo", atribuindo-se aos processos intuitivos papel relevante na formulação das hipóteses. ${ }^{78} \mathrm{O}$ segundo equívoco era a crença num único tipo universal de ciência, modelada segundo as matrizes da Biologia ou da Física, o que levou Pedro Lessa a recusar dignidade científica à Jurisprudência, por êle cultivada, aliás de maneira exímia, apenas e tão sòmente como Dogmática Jurídica, sem nos ter legado um só trabalho que servisse de modêlo ou de exemplo da planejada "ciência indutiva" do Direito...

Escapava-lhe, assim, o aspecto paradoxal de suas conclusões, eis que, julgando ter reivindicado o valor científico do Direito, cultivado tradicionalmente pelos "legistas" ou "juristas", acabara confiando exclusivamente à Sociologia Jurídica a tarefa da pesquisa científica, como pressuposto ou condição prévia do lavor artístico e subordinado dos "dogmáticos". .

Penso, ao contrário, que a Sociologia Jurídica e a Ciência do Direito se desenvolvem em planos distintos, havendo entre elas diferença de objeto e de estrutura metódica: enquanto a primeira é Ciência "puramente compreensiva", a segunda é de tipo "compreensivo-normativo". A Dogmática Jurídica, dessarte, não é algo de separado da Ciência do Direito, mas, ao contrário, constitui o momento culminante da Ciência Jurídica mesma, visto como, aos olhos do jurista, não há Direito até e enquanto não surja o momento essencial de normatividade. ${ }^{79}$

(77) Albert Einstein - Out of my later years, N. York, 1950, pág. 78 .

(78) Cfr. sôbre a atual metodologia científica e o valor da intuição o que escrevi em Filosofia do Direito, cit. passim.

(79) Sôbre tôdas essas questões básicas, que importam em total superamento do positivismo evolucionista de PEDro Lessa, cfr. meus 
VI

\section{Da condicionalidade transcendental à condicionalidade sociológica e a estatal do Direito}

17 - Não era senão aparentemente que Pedro Lessa partia indutivamente da observação dos fatos sociais, para atingir o seu conhecido conceito do Direito como "conjunto orgânico das condições de vida e desenvolvimento do indivíduo e da sociedade, dependentes da vontade humana, e que é necessária sejam garantidas pela fôrça coercitiva do Estado". 80

Esta definição, que chegou a se tornar clássica em nossos meios jurídicos, apesar das críticas veementes que lhe fizeram alguns neo-tomistas, suscita um problema bem mais importante do que o da apreciação externa de seus elementos nocionais, cuja aceitação ou rejeição se liga a uma série de pressupostos. Quero me referir ao emprêgo da categoria de condicionalidade no mundo do Direito.

Como se sabe, deve-se a Kant a poderosa visão do Direito em têrmos de condicionalidade e de heteronomia, tendo como fulcro o fator deontológico da liberdade, valor ético supremo que só pode ser limitado por si mesmo (só a liberdade é limite da liberdade, dirá depois GaBriEL Marcel) e que, por conseguinte, só pode ser concebido na universalidade ética das liberdades individuais coexistentes. Donde a clássica noção kantiana: "Direito é o conjunto das condições mediante as quais o arbítrio de cada um pode coexistir com o arbítrio dos demais, segundo uma lei universal de liberdade".

trabalhos Filosofia do Direito, cit.; Horizontes do Direito e da História, cit. e Aspectos da teoria tridimencional do Direito, separata da "Rev. da Fac. de Direito" de 1958.

(80) Estudos, cit., pág. 86. 
Mas o têrmo "condição" possui na teoria de KANT um especial significado lógico--transcendental, elemento constitutivo que é da experiência, como a priori que torna a experiência juridica possível. 0 conceito filosófico de Direito para Kant não é algo de transcendente (contraposto a imanente) mas sim transcendental (contraposto a empírico), sendo certo, porém, que todo transcendental, como Kant mesmo o diz, é a condição geral a priori em virtude da qual as coisas podem ser convertidas em objeto de nosso conhecimento, ou, por outras palavras, é condição geral de possibilidade de experiência.

A liberdade, no criticismo de Kant, é um valor que situa o homem num plano irredutível ao plano fenomenal, o que impede possa o homem ser concebido como algo integralmente inserido na causação universal. $O$ homem, pelo que nele necessàriamente existe de natureza, é causalmente determinado, como determinadas são as suas ações projetadas no mundo dos fenômenos; mas não o é em absoluto, na essência de seu ser pessoal que é a liberdade. Há, pois, na concepção kantiana, um dualismo entre "nôumeno" e "fenômeno", a que correspondem "liberdade" e "determinismo", como aspectos conciliáveis no ente humano. O homem é, ao mesmo tempo, "nôumeno" e "fenômeno", ser livre e ser causado, ou, como prefiro dizer, embora sob mais amplo prisma axiológico, "é síntese originária de ser e dever ser". ${ }^{81}$

(81) PEDro Lessa, em mais de uma oportunidade (v. Introdução, cit. pág. LXXIX, nota 126, e Estudos, cit., pág. 178), situou singelamente KANT entre os deterministas, por ter admitido, em sua Idéia de uma história natural, que "as ações humanas estão sujeitas ao império das leis universais da natureza, do mesmo modo que os outros fenômenos físicos, sejam quais forem" Equívoco tão grande como o de TOBIAS BARRETo ao apresentar-nos KANT como um monista... (v. Questões vigentes, cit., pág. 46). Tais afirmações, que já foram objeto de críticas mordazes e até mesmo irreverentes, revelam a incompreensão de certos estudiosos de formação positivista sôbre o que seja "a priori" e "transcendental" no criticismo. Ainda há pouco 
Pois bem, a categoria de condicionalidade, posta pelo filósofo de Koenigsberg como a raiz do Direito (a liberdade enquanto condicionada pela liberdade de outrem é o Direito), perde, logo a seguir, na doutrina de Krause, que tanta influência exerceu no mundo íbero-americano, a sua rigorosa significação lógico-transcendental, para englobar elementos empíricos de ordem psicológico-social. Para Krause, mestre de Ahrens e Tiberghien, o Direito é conjunto de condicões, mas, notem-se os acréscimos e o sentido bem diverso que a sua noção adquire: "Direito é a totalidade orgânica de tôdas as condições exteriores ou interiores para realizar a vida racional, na medida em que tais condições possam ser produzidas pela atividade livre". ${ }^{82}$

A Penro Lessa e a seus seguidores imediatos parece ter passado desapercebida a alteração essencial verificada no emprêgo da categoria de condicionalidade, como se Krause houvesse apenas enriquecido o conceito kantiano, sem lhe alterar o significado originário.

Assim é que José Mendes, um dos seguidores fiéis das doutrinas de LESSA, escreve: "o primeiro filósofo que empregou, na definição do Direito, a adequada, precisa e significativa palavra condiçäo, foi KANT. Mas quem concebeu a condição em seu sentido completo (sic) como o têrmo característico para exprimir as relações orgânicas de determinação, de ação e de influências recíprocas, em que existe e desenvolve-se também tudo no mundo moral e social, foi Krause" 83

tempo, um jovem professor de Filosofia não chegou a dizer, do alto de sua "capacidade profissional", que entre as categorias de KANT e as de ARISTóteles não há senão uma diferença terminológica?

(82) KRAUSE - Abriss der Rechtsphilosophie, 1928, págs. 8, 47.

(83) José Mendes — Ensáios de Filosofia do Direito, São Paulo, 1905, pág. 399. No plano crítico-transcendental, quem, na realidade, completou KANT foi HEGEL, com o seu conceito de "sociedade civil", momento intermédio entre o "indivíduo" abstrato e a sua "concreç̃o" na unidade ética do Estado. 
18 - Pois bem, quando pelo mundo íbero-americano se difundiram as teorias positivas, acentuando o sentido do fato social na concepção do Direito, uma das tendências mais fortes consistiu em dar ao têrmo condição, já denso de conteúdo social na teoria de Krause, uma acepção ajustada aos cânones das pesquisas sociológicas. Harmonizaram-se, dessarte, o positivismo evolucionista e o krausismo nos domínios do Direito e da Política, de tal sorte que o organicismo ético do filósofo alemão assumiu uma coloração empírica, com as características ideológicas de um "solidarismo social". ${ }^{84}$

Tal fato refletiu-se no conceito de Direito, de tal maneira que se generalizou o seu entendimento como "conjunto de condições de vida" Nesta ordem de idéias, é típica a posição assumida por LASTARRia ao propor "uma modificação na definição do Direito de Krause e Ahrens, no sentido de que as condiçổes externas e internas que constituem o Direito, dependam de cooperação humana, e não da liberdade, como pretendem aquêles filósofos" 85

Poder-se-ia aduzir que também a doutrina de JHering se mantém apegada à noção de condicionalidade, mas surge aqui um problema que é mister esclarecer, máxime em virtude da interpretação dada por Tobias Barreto, refletida em uma imperfeita compreensão do pensamento do mestre de $O$ espírito do Direito Romano.

Com efeito, uma terceira modificação deveria sobrevir ao conceito de condicionalidade por obra de JHERING, com quem o problema passa radicalmente para o plano empírico, à luz de sua compreensão teleológica dos interêsses que determinam a experiência jurídica. É o que clarameñte se expressa na sua definição: “Direito é a

(84) Sôbre o krausismo e o "direito social", v. GuRvitch - L'idée du droit social, Paris, 1922, págs. 442 e segs.

(85) Lastarria - Op. cit., pág. 113. 
forma da garantia das condições de vida da sociedade, assegurada pelo poder coercitivo do Estado". ${ }^{86}$

Na concepção de JHering, pois, as "condições de vida" representam o conteúdo do binômio formal constituído pela norma mais a coação, gue traduzem a "garantia" do Estado.

Dêsse modo, o conceito de Direito, que fôra condicionado ao individualismo liberal (coexistência ética de liberdades) por Emanuel Kant; e que adquirira um sentido de "condicionalidade social" na doutrina de Krause, sofre uma terceira refração, passando a ser condicionado pelo poder coercitivo do Estado (tese da estatalidade do Direito) no sistema de JHERING, apesar de subordinado finalìsticamente à realização "der Lebensbedingungen der Gesellschaft".

19 - Ora, nesse subtil "processus" evolutivo por que passou a categoria de "condicionalidade", seria temerário afirmar que Pedro Lessa tenha assumido posição própria, com total conhecimento da problemática subjacente; como também parece não ter dado valor ao poderoso esfôrço que, com Hegel e Marx, já se fizera para se conceber o Direito, não como "condição de vida", mas como "realização de vida" ou "objetivação do espírito". Seja-me lícito lembrar que segundo a minha concepção tridimensional do Direito, integrada na corrente histórico-cultural, o Direito é “a realização da convivência humana segundo uma orde-

(86) JHERING - Der zweck im Recht, 3.a ed., 1893, vol. I $\S 180$ "in fine": "die Form der durch die Zwangsgewalt des Staates beschaffen Sicherung der Lebensbedingungen der Gesellschaft". TOBIAS BARRETo, inadvertidamente, inverte o sentido do conceito de JHERING, pondo a tônica no elemento social (condição de vida) e não no elemento estatal (forma de garantia), ao dar-nos a seguinte tradução: "Direito é o conjunto de condições existenciais da sociedade coativamente asseguradas", a que êle acrescenta o epíteto "evolucionais", consoante ainda hoje é aceito por alguns juristas pátrios. (v. TOBIAs BARRETo - Estudos de Direito, Sergipe, 1926, vol. II, pág. 29). 
nação bilateral atributiva de valores" (um fato, pois, que se integra em normas atributivas, segundo valores), de forma que a "condicionalidade" lógico-transcendental de KANT vale apenas como momento originário e constitutivo do processo histórico do Direito, o qual se atualiza e se compreende dialèticamente, superadas as "condições" empíricas de ordem sociológica, psicológica, econômica, etc., que o "positivismo" em geral confundira com o Direito mesmo.

Em última análise, sob o prisma estrito de sua definição do Direito, Pedro Lessa poderia ser considerado um continuador do krausismo (foi êle discípulo de JoÄo TEODORo, seguidor eclético de Krause), mas de um krausismo refundido à luz de teorias biológicas e sociológicas, em pleno climax da Filosofia naturalista.

É a razão pela qual, a sua concepção do Direito acentua o elemento social das "condições de vida", assim como o elemento psicológico da vontade ("dependentes da vontade humana") e não o "poder de coação", à maneira de JHERING: a referência à coação, que é essencial no sistema do grande romanista germânico, permanece accessória no conceito de Pedro Lessa, que nos fala apenas em "necessidade de garantia pelo poder público", o que pode ser interpretado em têrmos de coercibilidade (coação virtual) e não como coercetividade (coação atual).

De qualquer forma, foi a de Pedro Lessa uma concepção do Direito achegada às "condições existenciais", um chamado vivo para a realidade social, o que constituiu uma contribuição preciosa numa terra tão seduzida pelos elementos extrínsecos, formais, quando não formalistas, da Jurisprudência.

Outubro de 1959 